\title{
CONSTRAINTS ON THE EVOLUTION AND THERMAL HISTORY OF THE CONTINENTAL PLATFORM OF SOUTHEAST BRAZIL, SÃO PAULO STATE, USING APATITE FISSION TRACK ANALYSIS (AFTA)
}

\section{SANDRO GUEDES DE OLIVEIRA ${ }^{1}$, PETER CHRISTIAN HACKSPACHER ${ }^{2}$, JÚLIO CÉSAR HADLER NETO*, PEDRO JOSÉ IUNES ${ }^{1}$, SÉRGIO ROBERTO DE PAULO ${ }^{3}$, LUIZ FELIPE BRANDINE RIBEIRO ${ }^{2}$ AND CARLOS ALBERTO TELLO SÁENZ ${ }^{2}$}

\begin{abstract}
Phanerozoic tectonic events in southeastern Brazil played an important role in the structuring of the South American Platform and its continental margin. During the Mesozoic the Pangea supercontinent was affected by rifting and continental separation processes resulting in the formation of a coastal margin basin associated with the uplift of the continental margin. These tectonic and epeirogenic processes were responsible for many of the present-day tectonic features and geomorphological characteristics of the region. Apatite Fission Track Analysis (AFTA) has been used for the determination of thermal histories and cooling ages, together with geological and geomorphological information, allowing to qualify and to quantify the timing of epeirogenic and tectonic processes. An AFTA study of a northwest-southeast profile, between the Mantiqueira Mountain Range (MMR) and the Atlantic Ocean, shows well-defined tectonic and thermal reworking. The thermal histories, of the different studied regions, show a similar uplift/denudation signature with a strong, tectonic controlled, uplift process. The thermal histories show that uplift started at 121 Ma in the Upper MMR, at 62 Ma for the lower MMR and 80 Ma for the Serra do Mar Mountain Range (SMMR). The Continental Platform of southeastern Brazil experienced a series of vertical and horizontal movements between the Cretaceous and the present day. A sequence of northeast-southeast blocks were uplifted, starting at different times but following similar patterns of evolution.
\end{abstract}

Keywords: AFTA, South American Platform, Cretaceous

\section{INTRODUCTION}

During the Early Paleozoic, the South American Platform experienced a period of stability followed by a phase of crustal doming (thickening) during the Permian, possibly due to disturbances considered to be caused by heating and thinning of the continental lithosphere. Cox (1989) correlated crustal thickening (underplating) observed in Namibia, Angola, in Africa, with southeastern Brazilian evolution. McKenzie (1984) and Cox (1989) associated this underplating to a hot spot. Pigeon (1985) and Lima et al (1999) related the epeirogenic uplifting of vast continental areas to an isostatic response to lithospheric thickening, resulting from the intrusion of great amounts of mafic magma, in the lower part of the crust. These magmas were also extruded as evidenced by the flood basalts of the Paraná-Etendeka Province

Almeida (1967) related this to the Wealdenian reactivation processes culminating at the Eoaptinian with the continental separation between Brazil and Africa. Alkaline magmatism and the large normal faults were associated with the generation of the MMR and SMMR (Asmus and Ferrari 1978).

Several authors considered that the MMR uplifted after the SMMR, (Fernandes 1993) and others considered their uplift to be simultaneous.

During the Eocene, a stable platform developed on the South American or Japi surface, later uplifted and reworked during the Oligocene (Freitas 1951, Almeida 1964). During this uplift event brittle faults reactivated preexisting, weaker, fault zones (Hackspacher et al. 1999). This is demonstrated by the presence of reactivation features in faults of the MMR during the Paleocene - Eocene. At that time, the Santos Basin was affected by thermomechanic tilting, creating extensional features in the NNW-SSE direction. A final extensional phase with NNW-SSE the NW-SE direction occurred during the Upper - Pleistocene and Holocene (Riccomini 1989). Later Neogenic surfaces formed during the Neogene and the lower Quaternary.

The purpose of this work is to demonstrate differential uplifts of blocks between the MMR and the coastline by means of their thermal histories (using AFTA), making it possible to reconstruct the geometric and temporal evolution of the region. This tectonic history is directly linked to the evolution of the South American Platform and continental margin.

METHOD AND RESULTS The apatite samples were collected along an approximately $250 \mathrm{~km}$ transect, from the western MMR to the coast, close to Ilhabela-SP (Fig. 1). The separation and concentration of the apatite followed Ribeiro's method (1996) and irradiation was done as described in Bigazzi et al. (2000). Analysis of fission tracks using the optical microscope were performed using the methods outlined in Tello $(1994,1998)$ and Hadler et al. $(1995,2000)$.
Thermal histories were obtained using the empirical model developed by Australian researchers Green et al. (1986), Lasllet et al. (1987), Duddy et al. (1988), Green et al. (1989), subsequently complemented and refined by Lutz and Omar (1991).

The methodology was used to define common thermal history for a group of samples that possess similar geological characteristics. This technique can furnish conclusive results using a smaller number of samples (Amaral et al. 1995, 1997, Hadler et at. 1995, Guedes et al. 2000). In the studied area (Fig. 1 and 2) the samples were grouped according to common geological characteristics such as: i) rock type, ii) proximity to faults, iii) geomorphology, and iv) apparent age. These criteria were used to classify the following groups of samples: MMR above $1000 \mathrm{~m}$ (TF-9 and TF-10), MMR below $1000 \mathrm{~m}$ (TF-12, TF-13) and SMMR (TF-21 and TF-22) (Table 1).

The thermal histories obtained in each group are given in Figure 3. It shows that the thermal histories are as follows: Upper MMR begins to uplift at $\sim 121 \mathrm{Ma}$, the lower MMR at $\sim 62 \mathrm{Ma}$, and the SMMR at $\sim 80 \mathrm{Ma}$

Table 1 - Results of the apparent (Tap) and corrected ages (Tcorr).

\begin{tabular}{|c|c|c|c|c|c|c|}
\hline & \multicolumn{2}{|c|}{ Mean age } & \multicolumn{4}{c|}{ Test $\chi^{2}$} \\
\hline Sample & $\begin{array}{c}\mathrm{T}_{\text {ap }} \\
(\mathrm{Ma})\end{array}$ & $\begin{array}{c}\mathrm{T}_{\text {corr }} \\
(\mathrm{Ma})\end{array}$ & $\begin{array}{c}\text { For mean ap. } \\
\text { age. }\end{array}$ & \multicolumn{2}{c|}{$\begin{array}{c}\text { For mean } \\
\text { corr. age }\end{array}$} \\
\hline & & & $\chi_{v}{ }^{2}$ & $\mathrm{P}_{\gamma v 2}$ & $\chi_{v}{ }^{2}$ & $\mathrm{P}_{\chi v 2}$ \\
\hline TF-9, TF-10 & $86 \pm 6$ & $121 \pm 9$ & 0.60 & 0.45 & 0.46 & 0.50 \\
\hline TF-12, TF-13 & $46 \pm 3$ & $62 \pm 5$ & 0.25 & 0.60 & 0.74 & 0.40 \\
\hline TF-21, TF-22 & $58 \pm 4$ & $80 \pm 6$ & 0.88 & 0.50 & 1.73 & 0.15 \\
\hline
\end{tabular}

DISCUSSIONS The AFTA shows that the upper MMR was affected by an initial uplift at $121 \mathrm{Ma}$, and underwent a slow cooling/ uplift until the Plio-Pleistocene. The lower MMR did not begin its uplift process until $62 \mathrm{Ma}$, but experienced also slow cooling until the Plio-Pleistocene. To the east, the uplift in the SMMR and the coastal block was initiated at $80 \mathrm{Ma}$, also followed by slow cooling until the Plio-pleistocene.

The difference in the corrected ages of the upper and lower MMR and the SMMR can not be explained by the difference of altitude alone. A tectonic process (Hackspacher et al. 1999) must have initiated 


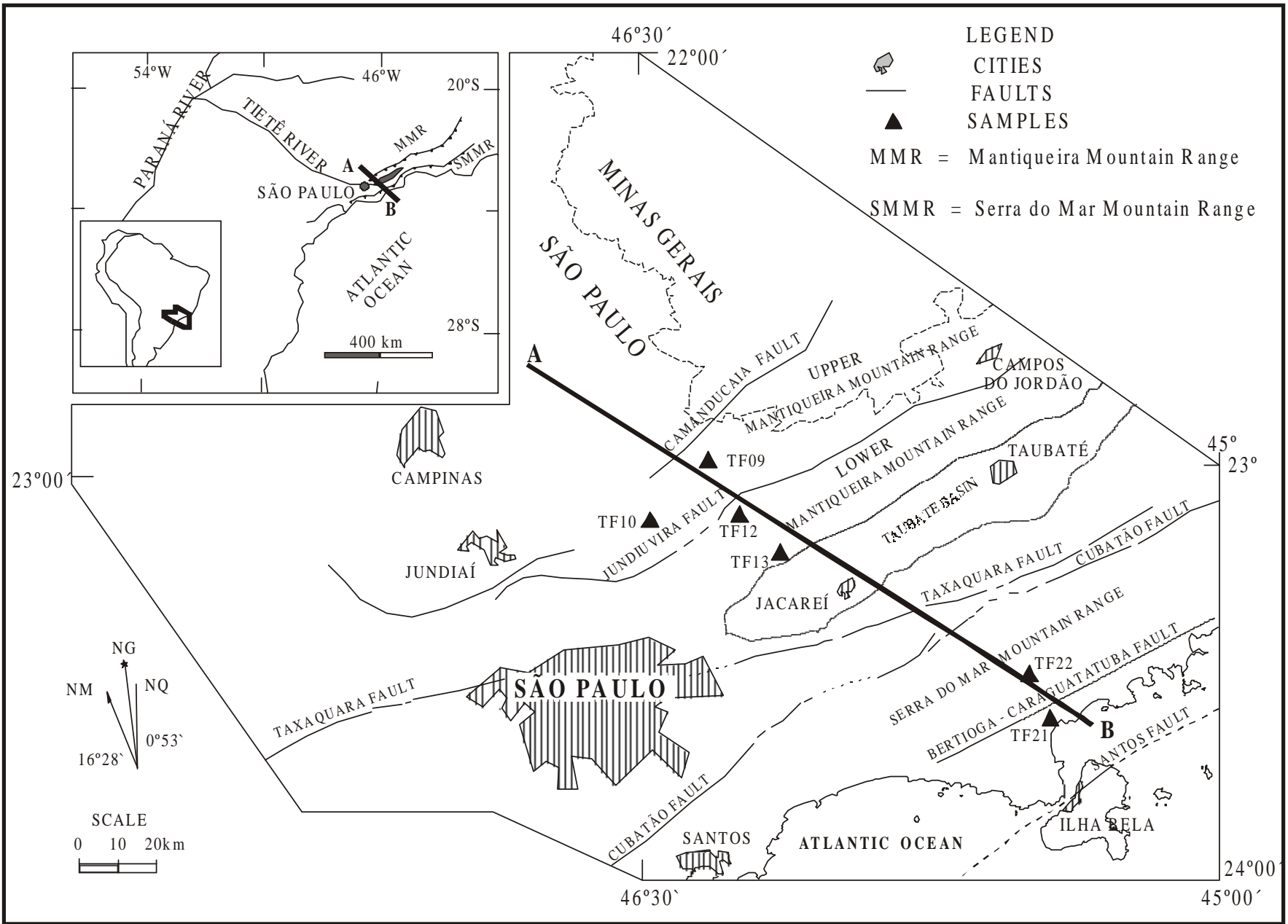

Figure 1 - Schematic regional sketch map with sample locations and main physiographic features. Modified after the geological sheets 1:250 000 of Guaratinguetá, São Paulo, Campinas and Santos, (DAAE/UNESP 1984)

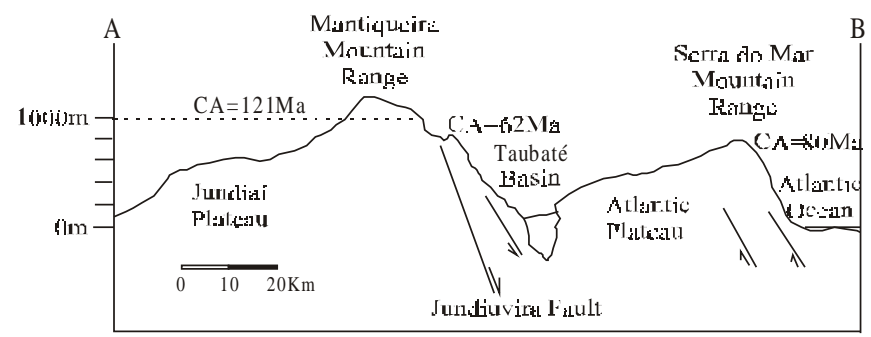

Figure 2 - Topographic section with values of the corrected ages $(C A)$ obtained by AFTA

the uplift process in the different regions at 121,80 and $62 \mathrm{Ma}$. A slow cooling/uplift following the tectonism is probably responsible for the actual morphology.

The regional uplift process was recognized by Freitas (1951) and Almeida (1964), and related to the concomitant South American peneplanation, registered through some preserved geomorphological surface at the MMR and SMMR. Both authors also suggested a progressive peneplanation of the entire region, related to the structuring of the Taubaté Basin.

Freitas (1951) described the peneplanation above the SMMR as happening just after it (SMMR) formation, which he denominates as level "B", in the upper MMR it surface was later reworked. Almeida (1964) called this level "Japi" and King (1957) South American.

From the Plio-Pleistocene (2 Ma) a strong regional, common, uplift process was registered by the different thermal histories obtained by AFTA in this work. The strong change between the thermal histories before and during the Plio-Pleistocene, around 2 Ma must be related to a common tectonic event. About $1.8 \mathrm{~km}$ must have been uplifted and eroded (Hackspacher et al. 1999) over the entire region.

The data above demonstrate the occurrence of several tectonic pulses, associated with epeirogenic processes.

The results obtained by the AFTA method, leads to conclude that the MMR is a structural feature of a half-graben for4med during continental rupture, with a complex subsequent evolution which included isostatic phenomena, denudation and uplift related to fault reactivation in a transpressional stress regime (Ribeiro 1996).

The analyses of paleosurfaces can be quantified through AFTA, defining a new tool for geomorphological and erosional studies.

CONCLUSIONS The Meso-Cenozoic morphotectonic history played an important role in the shaping the current configuration of the platform and continental margin. The upper and the lower MMR, the SMMR and the coastline record different initial tectonic histories, related to the thermal histories, followed by a similar morphotectonic history, of the different blocks. At the Upper Cretaceous/Lower Tertiary the lower MMR suffered a tectonic reactivation chronocorrelative to the sedimentation of the Taubaté Basin. The breaks in the inclinations of the thermal histories reflect a common tectonic reactivation in all three regions during the Plio-Pleistocene. The result of these processes has representatives in the Brazilian continental margin, place of natural deposition of the eroded material.

Acknowledgments To the Departamento de Petrologia e Metalogenia, IGCE/UNESP and Departamento de Cronologia Raios Cósmicos, IFGW/UNICAMP for the use of it laboratories. To FAPESP for the financial support of Carlos A. Tello S. (Proc. 98/ 01988-8) and grants for field work (Proc. 95/4417-3), to CNPq for the financial support of Luiz Felipe Brandini Ribeiro (Proc. 143422/9600). To Fabiana C. Silva and Fulvia Codazzi for assistance with illustrations. To the anonymous referees of RBG for the suggestions and criticism of the manuscript. To Allen H. Fetter for his review of the english. 

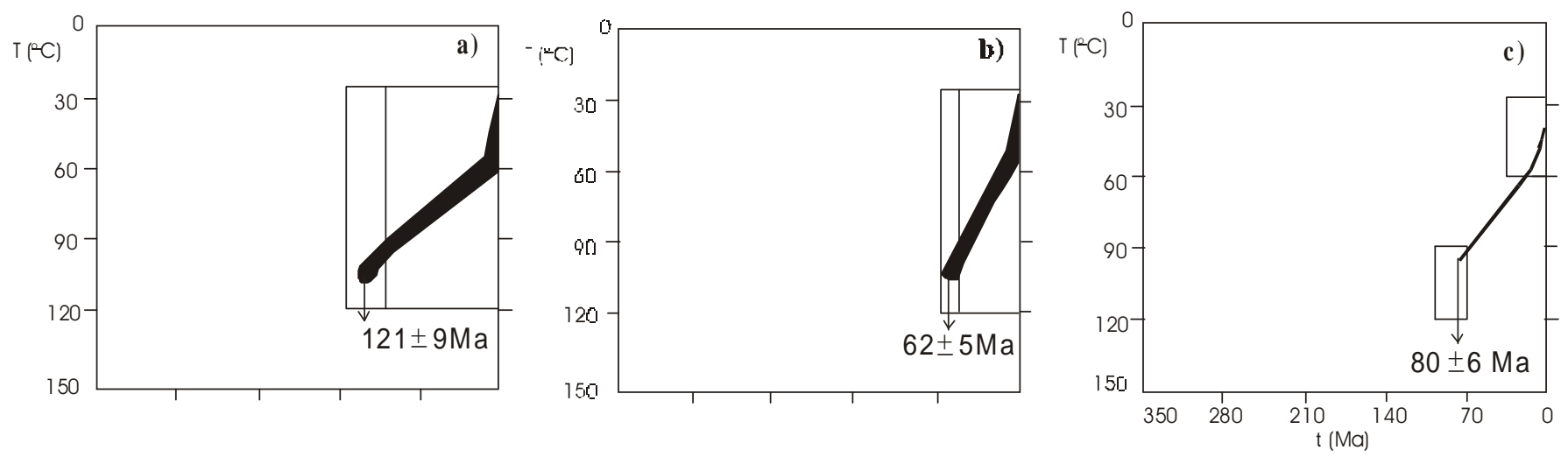

Figure 3 - Temperature versus time diagram with accepted thermal histories for each sample group and each corrected age. a) Upper Mantiqueira Mountain Range (upper $1000 \mathrm{~m}$ )- samples TF 9 and TF 10; b) Lower Mantiqueira Mountain Range (lower $1000 \mathrm{~m}$ )- samples TF 12 and TF 13; c) Serra do Mar Mountain Range- samples TF 21 and TF 22

\section{References}

Almeida F.F.M. de 1964. Fundamentos Geológicos do relevo Paulista. Boletim do IGG USP, 41:167-263.

Almeida F.F.M. de. 1967. Origem e Evolução da Plataforma Brasileira. Boletim do DNPM, 241:5-27.

Amaral G., Born H., Hadler N. J.C. Iunes P. Kawashita K, Machado Jr. D.L., Oliveira. E.P., Paulo S.R. and Tello S. C.A. 1995. Fission track analysis of adds brazilian apatites. Radiation Measurements, 25:499-502.

Amaral G., Born HO., Hadler N.J.C. Iunes P.J., Kawashita K., Machado Jr. D.L., Oliveira E.P., Paulo S.R., Tello S.C.A. 1997. Fission track analysis from San Francisco Craton and Mesozoic Alcaline - Carbonatite Complexes Central from Southesastern Brazil. Journal of South American Earth Sciences, 10:285-294.

Asmus H.E, Ferrari A.L. 1978. Hipótese sobre o tectonismo cenozóico na região sudeste do Brasil. Série projetos REMAC, 4 (PETROBRAS, CEMPES, DINTEP):75-88.

Bigazzi G., Guedes S., Hadler N.J.C., Iunes P.J., Paulo S.R., Tello S.C.A. 2000. Application of Neutron Dosymetry by Natural Uranium and Thorium Thin Films in Fisssion Track Dating. 9th International Conference on Fission Track Dating and Thermocronology, Extend abstract, 33-35. Lorne, Australia.

Cox K.G. 1989. The role of mantle plumes in the development of continental drainage patterns, Nature 342:873-877.

DAAE/UNESP 1984. Geological sheets 1:250 000 of Guaratinguetá, São Paulo, Campinas and Santos. DAAE-SP

Duddy I.R., Green P.F., Laslett G.M. 1988. Thermal annealing of fission tracks in apatite. 3.Variable temperature behaviour. Chemical . Geology, 73:25-38.

Fernandes F.L. 1993. Arcabouço estrutural e evolução da Bacia de Taubaté - SP. M.Sc. thesis, Escola de Minas, UFOP, Ouro Preto Brasil, 147+7pp.

Freitas R.O. 1951. Relevos Policíclicos na tectônica do escudo Brasileiro. Boletim Paulista Geociências, 7:3-19.

Green P.F. Duddy I.R. Gleadow A.J.W. Tingate P.R. and Laslett G.M. 1986. Thermal annealing of fission tracks in apatite, 1 . The qualitative description. Chemical. Geolology, 59:237-253.

Green P.F., Duddy I.R., Laslett G.M., Hegarty K.A., Gleadow A.J.W., Lovering J.F. 1989. Thermal annealing of fission track in apatite 4. Quantitative modeling techniques and extension to geological timescales. Chemical. Geology, 79:155-182.

Guedes O. S., Hadler N.J.C., Iunes P.J., Paulo S.R., Tello S.C.A. 2000. Recognition of Cretaceous, Paleocene and Plio-Pleistocene Activities, through AFTA, in Precambrian Areas of the Southeast Brazil: Association with the South Atlantic Ocean Opening. 9th International Conference on Fission Track Dating and Ocean Opening. 9th International Conference on Fission

Hackspacher P.C. Hadler N, J.C Iunes P. J., Paulo S.R., Ribeiro L.FB., Tello S.C.A. 1999 Alguns dados sobre o período Cretáceo na Serra da Mantiqueira através de análise de traços de fissão em apatitas (atfa). $5^{\circ}$ Simpósio Sobre o Cretáceo do Brasill/ $1^{o}$
Simpósio Sobre el Cretáceo de America del Sur. Boletim de resumos espandidos, 33-37, Serra Negra, São Paulo, Brasil.

Hadler N. J.C. Iunes PJ., Paulo S.R. Tello S.C. A. 1995. Obtencão de historias térmicas de varias regiões geologicamente compatíveis usando análise de traços de fissão em apatitas. Revista brasileira de Física Aplicada e Instrumentação.10:1-10.

Hadler N.J.C., Iunes P.J., Paulo S.R., Tello S.C.A. 2000. The Study of Apatite Fission Track Annealing: Experimental Measurements of Density and Length in Basal and Randomly Oriented Faces. 9th International Conference on Fission Track Dating and Thermocronology, , Extend abstracts, 143-145, Lorne, Australia

King, L.C. 1956. A geomorfologia do Brasil Oriental. Revista Brasileira de Geografia, 18: $147-265$.

Laslett G.M., Green P.F., Duddy I.R., Gleadow A.J.W. 1987. Thermal annealing of fission tracks in apatite 2 . The quantitative analysis, Chemical. Geology, 65, 1-13.

Lutz. T.M., Omar G. 1991. An inverse Method of modeling thermal histories from apatite fission-track it dates. Earth and Planetary Science Letters, 104,:181-195.

Lima C., Amaral C., Moraes A.E., Maia A. 1999. Are the large wave-length South American intraplate deformaton and the incipient inversion of Brazilian continental basins manifestations of ongoig lithospheric/crustal folding?. $6^{\circ}$ International congress of the Brazilian Geophisical Society, SBGf, 30-35, Rio de Janeiro, Rj, Brazil.

MCKenzie D P 1984 A possible mechanism for epeirogenic uplift Nature, 307:616-618.

Pigeon P. 1985. Les releves de Látlantique Sud vous donnez le bordiers de continents en Angola et au Brésil: notion du la du vers de thermiques du relifs. Geociências, São Angola et au B

Ricommini C. 1989. O Rift continental do sudeste do Brasil. PhD Thesis, São Paulo: Instituto de Geociências, USP, São Paulo, Brasil, 256pp.

Ribeiro L.F.B. 1996. Tectônica ressurgente da borda sul da Serra da Mantiqueira: geologia estrutural e datações por traços de fissão. M.Sc. Thesis. Instituto de Geociências e ciências exatas, UNESP, Rio Claro, Brasil, 200p.

Tello S.C.A. 1994. Termocronologia de algumas apatitas Brasileiras através da análise de traços de fissão. M.Sc. Thesis. Instituto de física Gleb Wataghin, UNICAMP, Campinas, Brasil, 103 p.

Tello S.C.A. 1998. Estudo de annealing de traços de fissão em apatitas, tanto em seções basais quanto em seç̃es sem orientação preferencial, análise dos comprimentos dos traços de fissão. PhD. Thesis, Instituto de Física Gleb Wataghin, UNICAMP, Campinas, Brasil, $111 \mathrm{p}$
Contribution IGC-133 Received March 1, 2000 Accepted for publication April 28,2000 